\title{
Is dominant logic a value or a liability? On the explorative turn in the German power utility industry
}

\section{Ekaterina Brandtner ${ }^{1}$ iD, Jörg Freiling ${ }^{2}$}

\begin{abstract}
Purpose: This study seeks to specify the role of 'dominant logic' in an organization. So doing, the ambiguous character of the dominant logic emerges, as on the one hand, a dominant logic can make sense of a change, provide useful guidelines and keep the company focused. However, on the other hand, a dominant logic may provide reasons why preventing change could be 'logical' or work as a blinder when it comes to interpreting up-and-coming developments. Therefore, a dominant logic can be a value and a liability in times of change. Methodology: This study sets out to contribute to prior research by raising two questions. First, how can we reconceptualize the construct of dominant logic to address both the driving and the hampering role in the case of explorative turns? And, second, which factors restrain and which allow explorative turns? With special regard to the German energy transition in the 2010s, this research grounds on explorative qualitative empirical research and employs a single case-study design for a traditional German power utility company, which - as an incumbent-has to deal with the high complexity in the German power industry. Data sources are in-depth and problem-centered interviews with both internal and external experts as well as field observations. An inductive procedure allows the development of research propositions from data, framed by prior research. Findings: As a result, this study delivers a six-factor framework to shine a light on the micro-foundations of dominant logic. Whether a dominant logic is of value or is a liability in organizational change and allows an explorative turn, depends on the identified abilities to unlearn, to explore, to change and to manage. Data suggests that an explorative turn, driven by dominant logic, works better in the case of combined learning and unlearning capacities, an ambidextrous balance of

1 Ekaterina Brandtner, Ph.D. candidate, Faculty for Business Studies and Economics, LEMEX - Chair for Small Business \& Entrepreneurship, University of Bremen, Enrique-Schmidt-Str. 1, 28359 Bremen, Germany, e-mail: ekbrandt@unibremen.de (ORCID: https://orcid.org/0000-0001-9016-2780).

2 Jörg Freiling, Prof. Dr., Faculty for Business Studies and Economics, LEMEX - Chair for Small Business \& Entrepreneurship, University of Bremen, Enrique-Schmidt-Str. 1, 28359 Bremen, Germany, e-mail: freiling@uni-bremen.de (ORCID: https:// orcid.org/0000-0001-6922-9805).
\end{abstract}


exploration and exploitation, co-existing logics, continuous adaptations of dominant logic and lower levels of leadership power and formal structures. Implications for theory and practice: This study specifies the roles of dominant logic that may hamper explorative turns in times of severe disruptions. Originality and value: It contributes to the research of managerial cognition by refining and applying the concept of dominant logic. It provides empirical evidence on how this phenomenon creates inertia, drives change, and discusses the needs for and the barriers to an explorative turn. From a managerial viewpoint, dominant logic serves as a filter to identify required changes and to tune the speed of change. This, however, depends on managerial reflection on the appropriateness of dominant logic in the run of events. Keywords: dominant logic, explorative turn, exploitation trap, German energy transition.

\section{INTRODUCTION}

Times of disruptive changes call for constructs that help companies to master the change. While in most recent times, technological developments like digitalization stand at the fore when it comes to analyzing disruptive change, sustainability and the related energy provision play an important role in terms of radical social and economic changes as well. With regard to incumbents, there is a strong need to adapt to these changes and, therefore, to 'reanimate' their explorative capabilities to avoid getting stuck in an 'exploitation trap' (Freiling, 2018). However, sometimes, the incumbents seem to be unable to move. One example is the rapid development of renewable energy sources, in connection with the current political pressure in terms of climate change. While this holds true for many countries worldwide, Germany is an extreme case due to massive changes in environmental public policy and legislation (Haake, 2015; Lee \& Lee, 2019). The term 'German Energiewende' (i.e., energy transition: an exit from nuclear and fossil energy and a move to sustainable energy sources) crystallizes the disruptive character of the major political and social changes caused by the Fukushima catastrophe (Beveridge \& Kern, 2013; Giones et al., 2018). As a consequence, incumbents had to develop completely new businesses and business models as the old ones broke down almost from one day to the other. In terms of ambidexterity (March, 1991), managers in the energy industry had to move from exploitation back to exploration to realize an explorative turn (Gibson \& Birkinshaw, 2004).

While it is still an open question as to how to master an explorative turn in formerly stable businesses like energy provision, the simultaneous pressure of digitalization and its imprint on strategy is strong (Buchan, 2012; Teece, 2018) and reconfiguring resources and capabilities must indispensably be followed by changing business models, organizational cultures and even 
company identities (Kor \& Mesko, 2013). Against this background, incumbent business models, existing structures, commitments and cognitive constraints prevent companies from explorative turns (Christensen, 1997; Desai, 2013). However, examples from other industries like the German company Linde show how dominant logic may drive change - here in the direction of permanent transformations towards up-and-coming trends and technologies like the fuel cell.

While the reasons for this resistance to change may be different, Prahalad and Bettis (1986) pointed to cognitive issues around 'dominant logic' (DL) as the "way in which managers conceptualize the business and make critical resource allocation decisions" (p. 490). As DL can drive or prevent disruptive change, DL comes into play when an explorative turn is required. Particularly in the case of strongly committed and traditional power utility companies, DL may relate to traditional ways of managerial thinking based on previous experience and accomplishments that make them stick to the old business and get stuck in an exploitation trap. Two faces of the DL debate appear: DL as a value when it leads to renewal and $D L$ as a liability when specific knowledge and old styles of thinking prevent the required changes. Accordingly, we raise two research questions:

RQ1) How to re-conceptualize the construct of the dominant logic to address both the driving and the hampering role in the case of explorative turns?

RQ2) Which factors restrain and which factors allow explorative turns?

The response to these questions is relevant, as the explorative turn in connection with an exploitative trap is a less understood phenomenon that relates to a wide number of industries. Currently, the automotive industry is undergoing a fundamental change, where incumbents still stick to previously learned ways of manufacturing combustion engines, trying to 'greenwash' business models and technologies (Fischedick \& Grunwald, 2017). Many established companies in mechanical and plant engineering still believe in the power of traditional ways of designing and tailoring solutions, with limited drive to move towards advanced 'industry 4.0' options. On the other hand, and on a more general level, societies recognize the power and potential of recent Al solutions - and this conviction currently opens many doors for change. While DL seems to be in place in all these cases, we still do not know very much of the ambiguous role of $D L$ in the context of rapid change. Facing the relevance of this issue, this paper makes a contribution to fill this relevant gap and aims at specifying this ambiguous, yet largely undiscovered role of $\mathrm{DL}$, by taking into account the time dimension. 
As for the contribution, the study enhances research on managerial cognition with an emphasis on the complex interplay between the individual, team and organizational level that allows an explanation of DL's ambiguity. A six-factor framework refines and structures the cornerstones of DL that are decisive to the value or liability role of the construct. Owing to the complexity of the research topic, a qualitative research design is chosen that rests on a single case study.

This article proceeds as follows: the next section provides the conceptual background and state of the art in the literature. Afterward, the methodology clarifies the epistemological frame and delivers details of the empirical fieldwork. It is followed by a section on the results that already comprises a discussion. The article ends with a section on conclusions and implications.

\section{CONCEPTUAL BACKGROUND}

This section seeks to clarify the core constructs in use. This step is connected with a literature review to locate the state of research.

\section{Dominant logic and its immanent ambiguity}

Basics of $D L$. Following the research line, the DL construct rests on beliefs, assumptions, experiences, and industry-specific identities with predictable models of behavior and action consequences (Bettis \& Prahalad, 1995). The discourse on DL in strategic management research is, to some extent, iterative. On this note, Bettis and Prahalad (1995) extended the above understanding and regard DL as "a fundamental aspect of organizational intelligence, whereas organizational learning can be thought of as occurring at the level of the strategy, systems, values, expectations and reinforced behaviors, which then shape the dominant logic through feedback" (p. 7). The ambiguity in definition highlights the complex nature of DL. Furthermore, a state of ambiguity implies complexity as well as uncertainty (Kaplan, 2008). This research aims to contribute to the conceptual development of a special view of DL as a barrier to and enabler of innovation by explaining how $\mathrm{DL}$ is related to organizational transformation and to shaping managerial decision-making, especially under time pressure and causal ambiguity (March, 1991). This balanced view of DL ties in with most recent discourses on hybrid phenomena like 'enabling constraints' (Selden \& Fletcher, 2015; Gancarczyk et al., 2021).

The roots of the DL phenomenon stem from cognitive psychology (Grant, 1988; Ginsberg, 1989). The DL concept rests on input from four streams of research on cognitive maps and problem-solving behaviour: "operant 
conditioning, paradigms, cognitive biases, and artificial intelligence" (Prahalad \& Bettis, 1986, p. 491). This traces back to Kelly's construction systems as "transparent patterns or templates, which he creates and then attempts to fit over the realities of which the world is composed" (Kelly, 1955, p. 7). In our case, this interrelation of thinking and acting, the management's interpretation of the environment, has a 'double effect' with positive (value) and negative (liability) impacts.

$D L$ and Liabilities. An important facet of DL relates to its consistency and rigidity (Blettner, 2008). Tversky compared people's internal representations to mental maps and cognitive biases in general, supported by mental collages and spatial mental models (Tversky, 1993). On the one hand, this mental mapping is an articulation of fundamental beliefs and expectations based on previous accomplishments and failures (Kor \& Mesko, 2013, p. 235). On the other hand, this can imply systematic errors or wrong judgments of the environment. Especially in times of rapid changes, these interpretations may be detrimental and end up in the least possible efforts or following old paths and learned rules (Greif \& Laitin, 2004).

Later contributions from research on organizational and institutional theory revealed change-inhibiting forces based on negative developments of a managerial logic and its adoption by organizations, which may result in technological, organizational, and strategic lock-ins (Sydow et al., 2009). The organization moves along its own path. Alternative ways and choices may remain hidden, as well as market changes ignored (Levitt \& March, 1988). Even signs of innovation tend to be seen as provocation or threat (Markides, 2006) rather than as an opportunity. Preservation of the well-known business and an (over-)emphasis on exploitation, based on firm routines, technological expertise, established learning styles or core competences (Leonard-Barton, 1992; Bettis \& Wang, 2003) seems to be 'logical' from this angle - a disruptive change, however, not. Based on empirical evidence in mechanical engineering, Freiling and Dressel (2015) found how a goods-dominant logic, developed and practised over decades, 'made sense' internally and prevented the unfolding of service-dominant logic (Vargo \& Lusch, 2004; Vargo \& Lusch, 2007).

$D L$ and Value. A firm's cognitive framework develops over time framed by resources, assets and knowledge and, on a different level, organizational boundaries. Each company has its own unique experiences with DL's emergence and its establishment within iterative learning processes. This influences a firm's resource allocation and competence configuration (Kor \& Mesko, 2013). Mental maps provide a firm-level information filter, even more, a "collective learning system" (Prahalad \& Hamel 1990, p. 82) and a knowledge set on how managers may trigger complexity and deal with information overload by using core capabilities (Leonard-Barton, 1992). 
$D L$, related to the firm's competence repository, available technology and market knowledge, may influence the strategic direction, firm's positioning, and the organizational intelligence (Bettis \& Prahalad, 1995) - with the latter shaped by individuals, their capability to interpret environmental dynamics and opportunities in rapid changes (Danneels, 2004). However, individual managerial mental activities are the basis for corporate value creation, strategy development, and a firm's performance in a core business through the application of specialized competences, previous experiences, and, not least, business failures (Greitemann et al., 2014). This all unveils the valuable nature of DL.

There is a growing interest in mental processes at an organizational level within management and organization literature, which triggered research on the wave of a 'cognitive revolution' (Butler et al., 2016). Only a few publications reveal empirical research findings with a focus on DL's deep dive into managerial cognition (Benner \& Tripsas, 2012; Raffaelli et al., 2019). Based on the longitudinal analysis, the purpose of this paper is to continue the controversial debate on the impact of $\mathrm{DL}$ on explorative turns versus exploitation traps. Drucker illustrated the role of managerial logics as follows: "The greatest danger in times of turbulence is not the turbulence - it is to act with yesterday's logic" (Drucker, 1980, p. 1). With the ambiguous role of $\mathrm{DL}$ as a driver and a barrier to innovation, there is a need for an analytical framework to consider this role more explicitly and to also consider the time dimension, which is a core purpose of this study.

\section{Dominant logic and the time dimension}

As $\mathrm{DL}$ evolves over time, the time dimension plays a significant role in the $\mathrm{DL}$ operationalization process. Especially in decision-making under radical uncertainty, the incumbent organization draws on values incorporated in available resources, knowledge, and capabilities. Whether an explorative turn takes place or the company fails to renew depends to some extent on overcoming resistance to change. Schumpeter (1934) conceptualized the notion of 'creative destruction' as a possibility to innovate or renew. So doing, he pointed already to the entrepreneurial power on the one hand and the conservative forces on the other. When creative destruction should unfold, the entrepreneurial power has to be stronger at a single point in time and during a running process. Following this thinking, Brandtner and Freiling (2019) elaborated that corporate innovation and transformation processes need an organizational turn from exploitation to exploration. Building on the creative destruction process, the old state has to be overcome and replaced. This, however, is counter-intuitive for many deciders, insofar as the old 
constellation is made of many valuable and appreciated things, reinforced by habits. Thus, there are reasons why an established constellation was dominant or still is. Over time, values emerged and abandoning them could cause a state of emptiness and disorientation (Brandtner \& Freiling, 2019). This gives rise to the impression that $\mathrm{DL}$ can be context-dependent and favoring an old business concept. In those cases, it could be that the logic needs to change to allow making sense of an explorative turn. In other cases, when such context dependence does not occur, the new constellation simply needs to make more sense to deciders individually and in groups. DL can prevent realizing ambidexterity and favor exploitation (Gibson \& Birkinshaw, 2004). In times of rapid changes and the need for more exploration, "the blinders of dominant logic" handicap the organization to recognize risks and chances (Prahalad 2004, p. 172).

When entire paradigms for thinking and acting in terms of doing business are changing, organizations involved in these businesses need to provide a response in different regards. This holds true particularly for the ongoing digital transformation that often not only changes the rules of the market but opens completely new markets. In these settings, the response implies continuous changes of organizational structures, strategies, and business models (Slater \& Mohr, 2006; Pan, 2017; Ross, 2019). This is difficult to achieve, insofar as digital transformation is about how technology changes the conditions under which business is done (Kane, 2017), as well as aligning the enterprises' culture and people with the digital strategy. Wessel et al. (2020) developed a process model to distinguish between different types of transformation, based on case-study research, and found out: "Digital transformation involves a new organizational identity compared with IT-enabled organizational transformation that enhances an existing organizational identity" (Wessel et al., 2020, p. 1).

In 2015, the Global Center for Digital Business Transformation launched a series of biennial studies to understand better attitudes and behaviors towards digital disruption in selected industries. Digital Vortex 2019, the third of these studies, showed " $(. .$.$) that all 14$ industries have moved closer to the center of the vortex, where the velocity and magnitude of change are highest" (Digital Vortex, 2019, p. 4). The energy and utilities sector, ranking $\# 13$, is one of the industries already dragged into the digital vortex, although it is moving at the moment along the edge. This implies that energy companies have a bit more time for preparation. However, in the last few years, the progress was anything but convincing. "Energy companies have failed to achieve substantial business value from digital because their approaches do not account for the unique challenges of being an energy company, which create extraordinary inertia" (Booth et al., 2020, p. 2). Following Booth et 
al. (2020), the companies are still not committed enough to overcome this inertia. Cognitive restraints work as innovation barriers and limit learning for necessary changes, while flexibility and values become decisive factors for competitiveness in the digital revolution (Prahalad, 2004; Friedrich von den Eichen et al., 2015). Booth et al. (2020) add regarding the energy industry that "the mindset of business executives has evolved over the years, but still not enough" (p. 5).

When rapid and major changes are not necessary in' normal times', DL provides stability and accompanies corporate culture with a shared philosophy, identity, and a way of doing business (Weick \& Sutcliffe, 2007). These operational characteristics are important for sustainability and improvement of the exploitation activities of the current business based on existing resources (Helfat \& Martin, 2015). Over time, it may constrain managers' attention to the extent that they do not see (strategic) real options (Collan et al., 2014), so that 'cognitive rigidities' and 'cognitive inertia' occur (Hodgkinson \& Wright, 2002). The stabilizing effect of $\mathrm{DL}$ initially protects companies from complexity (value), but finally, DL becomes resistant to change (liability) and turns into an innovation barrier: "exploitation wins over exploration" (Danneels, 2004, p. 3) and an exploitation trap occurs (Freiling, 2018).

The time dimension refers to the fact that $\mathrm{DL}$ emergence builds on two value-creating factors: competence repositories and organizational memory. Organizational memory collects and condenses past events (Govindarajan, 2012). At the same time, organizational memory creates preventive mechanisms against (extensive) change and innovation. For instance, the time dimension refers to prior experience and established routines so that DL does not develop 'overnight.' This opens the door for the need to unlearn when modifying or breaking old paths (Wang et al., 2016; Chlebna \& Simmie, 2018).

\section{Elements of the dominant logic in the light of the ambidextrous tension}

According to the research questions, this study targets $\mathrm{DL}$ determinants that consider both the driving and constraining role DL plays when it comes to disruptive change. The original DL concept and further research on DL and interlinked concepts reveal four fundamental model components: value and expectations, competitive strategy, measures of performance, and reinforced behavior (Bettis \& Prahalad, 1995). Prior research already suggests factors that drive the interplay of the four components. Prahalad and Bettis (1986) refer to business success in the past. Several scholars pointed to the enabling and constraining role of core competences (Leonard-Barton, 1992; Freiling 
et al., 2008; Greitemann et al., 2014) that form and enable dominant logic. Structural rigidity and cost traps are another reason why it may be 'logical' to stay rather than to move (Kor \& Mesko, 2013; Shollo \& Constantiou, 2013). As another factor set, the knowledge potential, the learning capability and the readiness to unlearn are important cornerstones of $D L$ and may impact an explorative momentum (Teece, 2007; Gavetti, 2011). The same holds for managerial risk aversion and complexity reduction (Prahalad \& Bettis, 1986) and communication and information behavior (Walsh, 1995; Bettis \& Wong, 2003). With these cornerstones in mind, the empirical challenge appears to learn from case evidence. The context is a rather conservative industry under the highest pressure to change. Synthesizing the findings of this section and relating them to earlier publications allows the following condensation and systematization of factors that the next sections can build on:

1) Prahalad and Bettis (1986) highlighted the relevance of past experiences in managing business. We label this factor (A) as business success in the past.

2) Various authors described the role of organizational and managerial capabilities, rigidities and competences in the core business (Prahalad \& Hamel, 1990; Leonard-Barton, 1992; Greitemann et al., 2014). We label this factor (B) as core competence dependence.

3) Recent research on structural rigidity (Leonard-Barton, 1992) and cost traps (Kor \& Mesko, 2013; Shollo \& Constantiou, 2013) allowed deeper access to understanding conventional business logics. We combined these characteristics in one factor $(\mathrm{C})$ we named structural rigidity and cost trap.

4) Some authors stressed the relevance of knowledge and organizational learning processes. We followed the suggestion of Teece $(2007,2016)$ and Gavetti (2012) to consider a factor (D) named knowledge potential and learning capability.

5) As a reflection of the environmental requierements and the managerial handling of huge data flows (Teece, 2016; Bettis \& Prahalad, 1995) we consider risk aversion and complexity reduction as factor (E).

6) According to prior research, DL influences communication styles and information handling (Walsh, 1995; Bettis \& Wong, 2003), that crystalized communication and information behavior (factor $\mathrm{F}$ ).

In the empirical analysis, we refer to these factors for the aggregation of the theoretical dimensions whenever data suggests this. However, as the methodological section shows, our procedure is data-driven and open for new findings beyond these crystallized factors. 


\section{METHODOLOGY}

This section seeks to clarify the epistemological foundations by specifying and explaining the research design. Afterwards, the procedures of data selection and analysis are explained.

\section{Research design}

Due to the complexity of the research object, this study rests on social constructivism and employs an explorative qualitative research design to respond to the nature of the research questions raised above (Kukla, 2000; Yin, 2014). As a rather 'sticky' construct relevant to individual, group and organizational decision-making, it is deemed important to gather in-depth data from multiple perspectives. As the companies in the respective power utility industry are big and complex, the choice of a single case-study design appears to be useful (Yin, 2014). To be open to new findings, this study employs an inductive approach that starts analyzing with data from the field. However, to consider the findings in the literature, the procedure follows the Gioia et al. (2013) procedure of a systematic inductive approach that allows structuring and interpreting data by using established frames and findings from prior research.

\section{Data deletion}

A single case on a complex phenomenon requires the extensive on-site experience of the authors' observations to allow cognitive insights on the drivers and barriers of organizational innovation related to DL (Huff, 1997). The selection criteria to identify the case company are: (i) power utility focus to ensure that the business is under the strong pressure of the 'Energiewende,' (ii) business focus in Germany for the same reason, (iii) age and tradition to allow the development of a strong DL and (iv) size to identify complex settings. To avoid biases by triangulation, the data stems from different sources. The prime data source is in-depth interviews. To allow unexpected findings, the interviews are semi-structured with a narrative section right at the beginning and followed by a set of follow-up questions closely related to the research questions.

The number of interviews should follow the data saturation principle, according to Yin (2014), so that no more interviews were scheduled in the case of only marginal additional insights of the last two. The total number of interviews is 13. As a first step of data triangulation, interviewees from inside the company (ten interviews) were chosen, as well as external experts 
(three in number) with intimate knowledge both about the company and the industry for triangulation purposes. First, triangulation of perspectives (internal/external) allows comparing findings from different sources of information and to reduce "false conclusions" (Hammersley, 2008, p. 23). Second, this implies a different understanding of DL based on 'confirmation bias' (Tversky \& Kahneman, 1974) and 'judgemental heuristics' provided by internal informants and external experts.

Internal experts are managers with responsibilities in the area of strategy, business model development, and implementation. We focused on decision-makers (Raynaud \& Arrow, 2013), senior managers, vice presidents and board members, as managers in these positions are involved in decisionmaking processes that shape the organizational path and leave an imprint on DL. For external experts, we deliberately chose experts from the power utility industry with independent perspectives and considerable expertise of at least the industry: consultants, competitors, and former managers. They validated findings as an accurate representation of the phenomenon and its impact on the organization.

For validation reasons, specifying the time sequence was important to set up an interview phase in the short time period from November 2016 till March 2017 - the peak of the transition debate in Germany. This is the point in time where energy companies in Germany stopped complaining and tried to go for explorative turns. This way, all interview partners have been on a similar level of awareness and information. Table 1 provides an overview of the interviews, the time when they were held, the duration, information on the interviewees, as well as the codes used for anonymized data analysis. Each interviewee got a unique study ID, which differentiates corporate affiliation (internals v. externals) and management level (first, second, third) of the interviewees. All interviews were held in German as the relevant business language and audio-recorded as well as transcribed.

In line with Wolfinger (2002), observation-based fieldnotes and secondary data from websites, social media and mass media accompanied the interview data. While the interviews are the prime data source, the observations and the secondary data sources are meaningful and useful to check and deepen the impressions of the interviews. The goal of the observation was to experience the way of thinking and action in the DL context by taking the entire atmosphere and the interactions of decision-makers into account. Observation memos helped to document the impressions and to consider them in the steps of data analysis. With intensive access to the case company, these fieldnotes are extensive and useful for identifying DL related topics and checking prior research findings in the light of the case setting. 


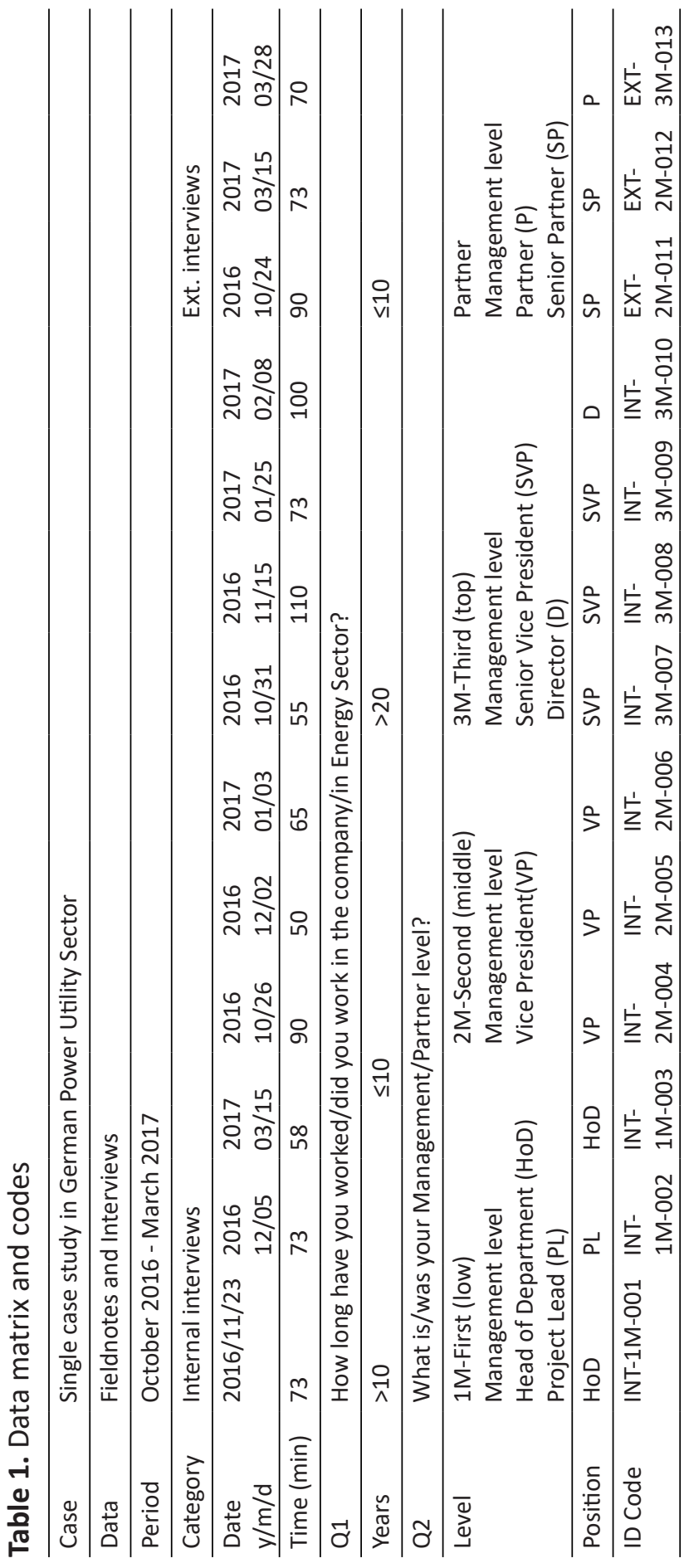




\section{Data analysis}

We employed a systematic inductive approach to condense and convert raw data into 1st- and 2nd-order categories (Gioia et al., 2013) - and to develop research propositions based on it. To identify relevant patterns and supported by MAXQDA as software for analyzing qualitative data, we conducted an open coding in line with Corbin \& Strauss (2008) based on a keyword search in the interview transcripts. First, we analyzed interview data and fieldnotes line by line to identify relevant statements on DL and paraphrases representing key findings. For example, the common statement in interviews: "We were successful and satisfied with the way things were going in the energy sector" was coded first as everything was better in the past and later this code was re-examined in fieldnotes and re-coded as $d$ welling on past success. Codes and categories were developed iteratively from the first to the last interview analysis. Afterward, the inductively generated codes were applied and aggregated to a list of concepts (1storder analysis according to Gioia et al., 2013).

In sum, we extracted 68 codes within the 1st-order analysis. At the next level of the data aggregation, we analyzed similarities and differences among the codes (Corbin \& Strauss, 2008). First-level codes, which represented similar ideas, have been grouped in higher-level categories where some of them became indicators. In sum, we identified 18 indicators that provide these category labels (Gioia et al., 2013) and evidence of managerial logic and its specific role. During the 2 nd-order analysis, we analyzed links between our findings and theoretical themes in the light of the research objectives. The data aggregation allowed explaining phenomena and re-examining theoretical dimensions (c.f., 'Conceptual Background').

Figure 1 provides an exemplified overview of how to move principally from raw data via 1st-order concepts and 2 nd-order themes to aggregate dimensions. The aggregate dimensions are core to responding to the research questions in terms of $D L$ related factors with impacts on driving or hampering explorative turns. Glaser and Strauss $(1967$, p. 45) coined this process as "theoretical sampling" followed by "theoretical saturation" that allows the aggregation of dimensions. The identified mechanisms allow insights on DL's impact on explorative turns as well as internal factors constituting DL. 


\begin{tabular}{|l|l|}
\hline \multicolumn{1}{|c|}{ 1st Order } & \multicolumn{1}{c|}{ 2nd Order } \\
Concepts
\end{tabular}

Figure 1. Example of the data structure of 'Factor $A$ '

However, when we analyzed interrelations between different factors and indicators, micro processes such as the capacities to unlearn, explore, change, and manage in digital frames of references appeared. This step was valuable to understand the impact of $\mathrm{DL}$ on explorative turns from a process view. For this reason, we re-examined our aggregated data with a focus on DL development with reference to the digital context (c.f., 'Results').

The preliminary coding of collected data helped achieve consistency (Charmaz, 2014) between observation memos, secondary data, and transcripts to generate a picture representing a firm's DL and its development. To ensure the validity of this picture, the findings were presented to a small circle of external experts. In line with Corbin and Strauss (2008), the communicative validation took place on different levels of the research process: (i) coding, (ii) theoretical saturation and (iii) re-conceptualization of DL. First, we discussed our initial results from the data aggregation process with experts for both a critical and a constructive reality check. When regarding the defined categories from the meta-perspective, they provided feedback on our handling of codes, themes, and theoretical dimensions. They provided some ideas about the interpretations of the original text sequences, which allowed a reduction in data complexity. Second, the experts checked the findings for an accurate representation of the phenomenon and its impact on organization. 


\section{RESULTS}

This section starts with a short overview of the case company and proceeds with data structured around the two research questions - responding to them one by one. The section concludes with a discussion.

\section{Case description}

The researched company is one of Germany's largest energy providers with a long tradition and an impressing track record. In response to political, social and economic requirements, the analysed company was split up in two separate units during this study. The first unit, with its core competences in conventional plant operations, was founded as a completely new company with a new brand, while the second one carried on the 'old' brand focussing on renewable energies, decentralized energy production, intelligent networks, and customer services. The organizational setting had been changed significantly and the focus of both parts of the company were increased by the change. However, the logics behind and the mindsets of the management did not need to change - and they did not change. This way, the 'old world' was transferred in a new setting - but not really transformed. The management team was divided into two teams, but essentially the staff did not change and stuck to the old way of doing business. They moved on, doing the same things, following the same routines and logics under a new brand: 'old wine in new bottles'. As mentioned before, this meets with the general observations in the energy industry: "Many energy executives have been at the same company for at least 30 years, rising through the ranks by running a well-worn playbook" (Booth et al., 2020, p. 4).

\section{Findings on the ambiguous role of DL (RQ1)}

Developing a data structure by way of "theoretical saturation" (Glaser \& Strauss, 1967, p. 45), we investigate whether it is possible to use a SixFactor framework (cf. 'Conceptual Background') to describe the phenomena we are observing. In our data gathering and interpretation process, we used our theoretical insights about six factors: $(A)$ business success in the past; (B) core competence dependence; (C) structural rigidity and cost trap; (D) knowledge potential and learning capability; (E) risk aversion and complexity reduction; (F) communication and information behavior. Moving back and forth in the available data, the analysis suggests high suitability of the condensation according to the conceptual background above. The 
analyzed data in balance with the theoretical insights support comprising a reconceptualization of $D L$ by six factors.

Against this background, a first contribution at reconceptualizing and refining DL is possible. Based on the Bettis and Prahalad (1995) illustration of $D L$ as an information funnel, we can modify the filter structure of DL. The six factors identified in the data, based on both theoretical and empirical findings, allow a more fine-grained understanding of the components that form DL. Consequently, Figure 2 considers these six factors in a cohesive framework building on Bettis and Prahalad's (1995) seminal work.

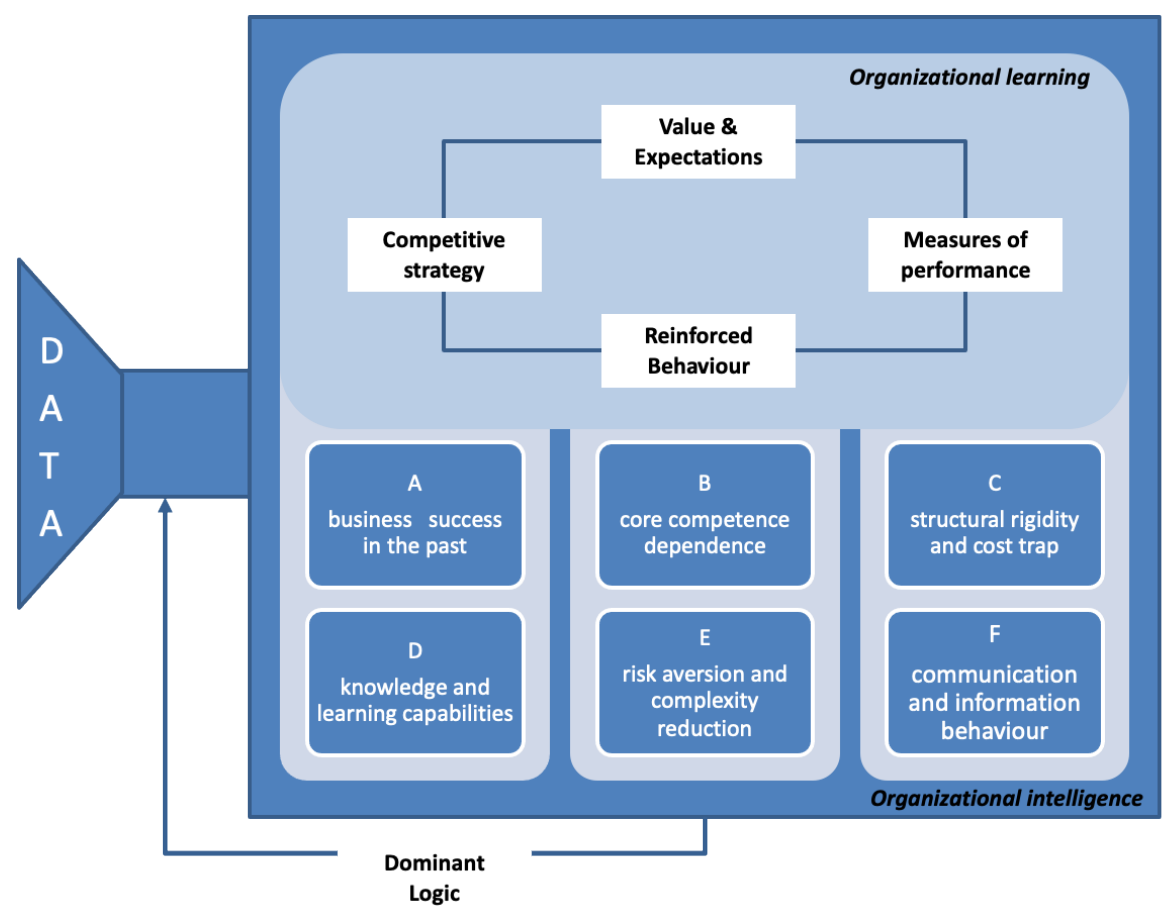

Figure 2. Reconceptualization of the Dominant Logic by a Six-Factor

\section{Framework}

Source: Own illustration based on Bettis and Prahalad (1995, p. 7).

Building on Bettis and Prahalad (1995), the huge amount of data is filtered by $\mathrm{DL}$ and incorporated into the organization with an impact on "the analytic procedures managers use to aid strategy development" and on "organizational learning" occurring at the level of the strategy, value, expectations, measure of performance and reinforced behavior (p. 7). We modified the funnel by adding in six factors belonging to the "organizational intelligence" (Bettis \& Prahalad, 1995, p. 7) as they shape managerial cognition and managerial 
decision-making processes in real time (c.f., the sub-section 'Dominant logic and its immanent ambiguity'). The orchestration of these factors is useful to understand frames of reference, particularly in times of rapid changes.

The model developed here sheds light on the impact of the combination of the different factors that constitute $\mathrm{DL}$ and cause a specific organizational behavior that permeates managerial decision-making and activates the driving or hampering role of DL. DL corresponds to environmental changes in different ways and depending on the equilibrium of the factors, it provides either value or liability. The set of coherent factors influence the development of $\mathrm{DL}$ in relation to the external environment and changing times. We investigate both the positive and negative effects of these factors (cf. Process facets). Especially, facing rapid changes like digitalization, inevitably affects strategic moves.

Therefore, it seems reasonable to assume that this modified comprehension of DL along these six factors (dimensions) helps to handle the ambidextrous character of DL (c.f., Conceptual Background). The modified structure reflects the complexity of the DL phenomenon. Inevitably, the list of factors may encompass relevant items that are context-dependent and generalized for further empirical analysis (Brown, 2015). Notably, the conceptualization of DL originates from the dynamic interplay of the six factors with a driving or preventive impact on an explorative turn during the disruptive changes in the German power utility sector.

Remarkably, the intra-organizational data sources allowed moving from initial data to themes, concepts, and dimensions. The results were discussed with external experts. The data analysis revealed that digitalization was one of the core topics when it comes to understanding the role of DL in the context of an explorative turn. In Figure 2, the data reveals to some extent how far the single perceptions of interviewees seem to translate into convictions shared at least at the team level, if not at the organizational level. Moreover, it shows skepticism whether an explorative turn of the digital kind may create value or destroy it. Accompanying observations confirm this to a large extent and reveal the relevance of an exploitation trap in terms of the opinion that digital moves are not necessarily better and that the organization needs time to prepare before starting to go in this direction. 


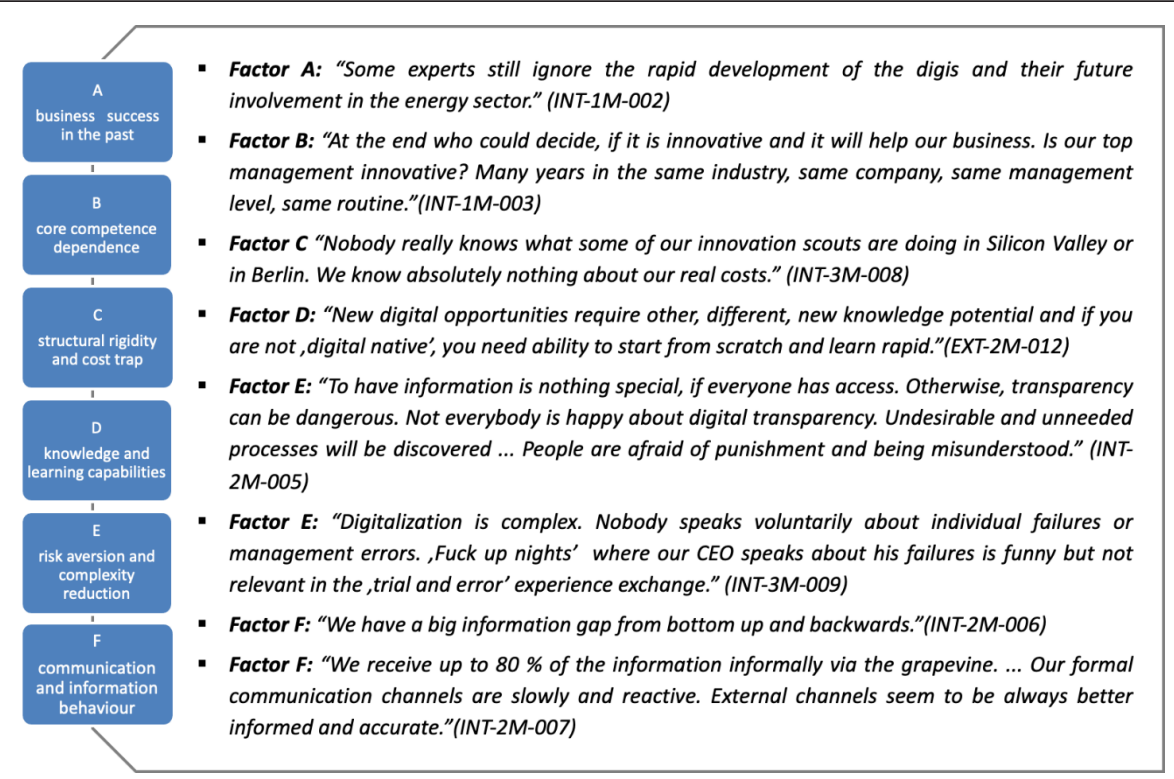

Figure 2. The evidence of DL in the digital context

\section{Findings on DL-related factors and the explorative turn (RQ2)}

To respond to RQ2, it is essential to understand the cognitive patterns that make it hard to move from an old business to a renewed one. The interconnection of factors and related indicators allows access to these patterns. We selected and analyzed argumentative indicators that are significant for an adequate reconstruction of determinants and result in an analytic overview of the mechanisms relevant to the challenge of the explorative turn. Indicators like 'arrogance,' 'nostalgia,' 'non-recognition,' 'dependency on traditional business model,' 'group thinking,' lock-in,' 'overoptimism,' 'fear of uncertainty,' 'allocation of blame' have been crystallized as 1st-order codes from data. A taxonomical order of indicators (resulting from the 1st-order analysis) provides an opportunity to align the visibility of the factor-indicator connection, to facilitate a better understanding of their interrelations and finally to explain the forces driving or constraining explorative turns.

The same indicator can address different factors, but which factor is really powerful in the end depends on a combination of indicators based on context. We recognized how relevant it is to pay attention to this interrelation. The nature of casual relationships with positive or negative connotations helps to describe and explain the impact of DL on explorative turns. In this context, 
data reveals four managerial capacities that strongly depend on $\mathrm{DL}$, namely the capacity to (i) unlearn, (ii) explore, (iii) change, and (iv) manage. Figure 3 portrays these processual capacities in the light of the six-factor framework developed above. The figure already comprises first paraphrases from the empirical data set. The three factors A, B and C structure DL in such a way that an exploitation trap is the result. This is only negative for the company in those cases when rapid changes are necessary (digitalization, energy transition). In the case of evolutionary change, however, the influence of factors $A, B$, and $C$ is a value for the company. It helps to focus and to keep track. If the target is to achieve an explorative turn, then factors $D, E$, and $F$ are crucial. They may re-animate the dormant capabilities needed for exploration and, thus, help reduce the liability impact of DL. These capacities allow a return to exploring new ways of doing business ('explorative turn'). However, their (re-) activation takes time within change processes. This often implies processes of unlearning, which are sometimes much more complicated and challenging as learning. The four managerial capacities influence $D L$ and allow explorative turns based on available data, which is explained in more detail below.

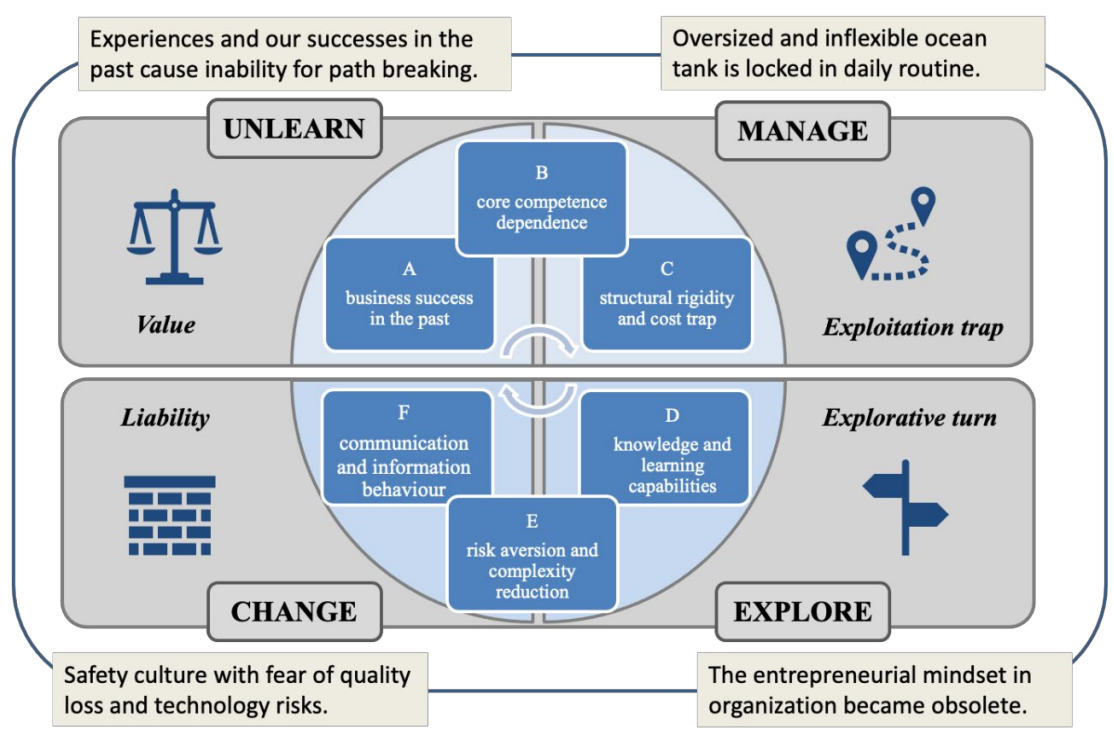

Figure 3. Managerial Process Capacities and the Six-Factor Framework

Capacity to unlearn. The capacity to unlearn is related to the role of open-mindedness versus inflexibility. A low capacity restricts the openness for the new digital opportunities. Dynamic use of digital networks may provide new experiences and digital knowledge. Technology knowledge and project 
experience occupied a prominent role in all interviews (Fieldnotes, 2016/11/20): The interviewed partners are proud of the company's experiences, knowledge potentials, and learning capablities based on core competences and business success in the past (factor D). Nevertheless, we identified discussions around the knowledge exchange between departments. Therefore, indicators like 'power position' or 'group thinking' describe internal interrelations. The majority of decisions is based on power or group dependency, less so on 'rational facts.' The business environment changes have been ignored for decades. This makes it easier to stick to previously learned and highly understood procedures and makes unlearning much harder.

Additionally, the frequently raised question, "Do we have the necessary qualifications, digital competencies, and right mindset in our house?," emphasizes the importance of companies' knowledge potential. Digital technology trends push out from the comfort and security zone and transcend the intimate knowledge base considerably. This requires acquiring new capabilities and different kinds of knowledge. The interviewed managers doubt about internal learning capabilities like "digital literacy" (INT-2M-002) and ways to overcome barriers based on collected experiences and past knowledge. According to the interviews, respondents believe that each learning process has to start on top of the company and to move strictly top down. One thing for them is clear (Fieldnotes, 2016/11/20): Continuous learning outside of the box, outside of the energy sector, could help the company avoid the insufficient perception of the urgency due to the rapid business environment changes. Significant amounts of digital products are there, thus, customers expect from the energy sector new solutions and products with service levels they have experienced in other industries. In this regard, it is important to start with the end user needs: "to learn fast or to forget what we know ... our knowledge plays against us" (INT-3M-009). Unlearning as a process capacity may only unfold if new and better knowledge is available and to some extent understood, in order to move from exploitation to exploration with a certain conviction to master the change. Research proposition 1 (RP1) mirrors this:

\section{$R P 1)$ Explorative DL-driven turns rest on combined learning and unlearning capacities.}

Capacity to explore. The narrative part of interviews shares the same elements (Fieldnotes, 2017/01/15): A majority of the interviewed managers stated that their company has a proven track record of success from the core business. This focus defined the business strategy for decades and caused a dependency, maybe to some extent an 'ideology.' This belief in their own core competence could be an explanation for a strict resource allocation 
and an investment program with extreme focus on geographical expansion and asset strategy, however less so on business model innovation. An assetintensive company, like the one under focus, clings to their assets which have always been the fundament for new projects and optimization of the current technologies. For decades, energy managers seem to have done well, but suddenly they recognized a downward spiral.

The negative connotation of core competence is linked with a sense of distrust, fear of uncertainty, non-recognition, and fear to be blamed. These key indicators from the interviews concern the dependency on the traditional way of doing business and uncertainty at the same time. Experts recognize that the core competence that predominantly worked well in 'normal' times turned to dependency and inflexibility under uncertainty - like the core rigidity notion of Leonard-Barton (1992) suggests. The competence trap creates resistance and fosters a "wait and see" (EXT-2M-012) attitude. A sense of urgency exists, but the explorative spirit has been lost decades ago.

Concerning business success in the past (factor A, Figure 2), we observed that it mainly relates to an ex-post way of thinking in the power utility sector with a distinct sense for history and tradition. This factor stands for a thinking decade backward. The former business model was successful for many years. The disruption, however, changes the situation completely. This reinforces a typical attitude of "everything was better in the past" (INT-2M-003). The narrative part of interviews reveals that some managers still hang on the past and wallow in nostalgia to cover themselves from all unknowns and unexposed realities. They are proud remembering the company's development after the liberalization of energy markets and during the internationalization phase as well as newly developed activities in Europe.

In the past, an established market position was based on strong brands, traditional technologies, access to resources, and customers - besides strong market regulations of the political kind. In the argumentative discourse, we found a linkage between successes in the past and establishing misconduct behavior. Keywords based on the analyzed context were identified as symbols for the formation of special attitudes in the company. The strong indicators materialize in keywords like arrogance, power, and over-optimism. Strategy failure and lack of success today refer to longitudinal and profound processes started in the past and significantly influence the future. The current business model was successful initially, but the new digital age forces a search for a new direction with an eventually disruptive impact.

Against this background, we can theorize on the capacity to explore. Cognitive limitations and a missing entrepreneurial mindset limit this capacity. The management seems to be urgently searching for new opportunities, innovations and for a vision and new ideas, but "the enterpreneurial mindset 
in the organisation became obsolete" (INT-3M-009). The willingness to face challenges is buried under fear and a huge number of exploitative activities that are time-consuming and restrain their creativity. The described current state is "the corporate management is running after ages of external moves without clear direction and the management on the business level is playing not to lose covered by a flurry of daily business" (INT-2M-010). To pave the way towards explorative turns, it is obviously useful to connect old and new businesses in terms of ambidexterity rather than running strictly on explorative paths, so we propose:

\section{RP2) Explorative DL-driven turns rest on a balance between 'exploitative' operational processes and 'explorative' activities.}

Capacity to change. Two topics seem decisive for an explorative turn: data transparency and open communication (factor F). The interviewed managers perceive that some action like data centralisation and democratization is required in all business sectors and departments. Nevertheless, they observe not only positive influences that are built on data transparency. Fieldnotes 2016/12/05: Some of the managers are afraid that confidential data could be interpreted wrongly or even misused. The transparency obviously scares. On the one hand, there is a fear of reduced or lost information power. On the other hand, there is a fear of disclosure and punishment, if "undesirable and unneeded processes will be discovered" (INT-2M-002).

The communication and information behavior depends on certain issues. The respondents are interested in new technologies, especially related to social media. All of them are sure that digital trends affect their life. Especially regarding digital transformation projects in the company, the state of information is different due to ignorance, cherry-picking, lack of interest, and lack of knowledge. Nevertheless, in the interview discussions we identified "limited" (INT-2M-003), sometimes "restricted" (INT-3M-008) communication behavior. Managerial experience with internal and external information exchange stimulates this behavior. The restricted communication style may interrupt information flows and favor 'grapevines' that could narrow the information gap, but even so exaggerate new fears. This limited internal communication confuses managers through bewildering rapid flows of external information.

The capacity to change relates to the role of organizational culture and self-reflexivity of the management. We find that a "safety culture" (EXT$2 \mathrm{M}-012$ ) endowment in the firm's way of doing business has a considerable effect on reduced exploration activity. The feeling of uncertainty describes the current state in the company. The 'digital age' has shaped two attitudes: 
over-optimism and over-estimating the probability of losses. Moreover, by impeding the level of self-reflexivity, these factors weaken the ability to sense opportunities and threats (Teece, 2007). Data reveals this dilemma. On the one hand, the interviewed managers showed an openness to digital innovation; on the other, they preferred to talk about future risks and losses in the business articulated in fear of "quality loss and technology risks" (INT-2M-003).

The interviewed managers related the high-risk aversion to the high complexity of the product 'energy' with all business levels involved. The "unsexy" product electricity is needed by "everyone, everyday and everywhere" (INT-2M-001). Fieldnotes 2017/01/25: This ' $E^{3}$ formula' gives managers a learned pattern of argumentation as to why it is so difficult, complex and hazardous. If somebody starts asking about change activities and innovation openess, he would be blocked and the most defensive responses would be linked to the complex technology and to the risk relevance. A fear of unknown changes refers to the company's risk-averse culture with focus on different present and historic matters rather than future issues. Running an existing business does not open the door for creative and explorative activities. Managers do not get the time and the resources for experiments or a true entrepreneurial passion. Relatedly, we propose:

\section{RP3(a). Explorative turns rest on different co-existing logics, enabled by organizational reflexivity and multiculturality. \\ $R P 3(b)$. Explorative turns rest on a continuous revision of $D L$, enabled by diversified businesses and flexibility in managerial action.}

Capacity to manage. Furthermore, the also addressed multicultural perspective forces the co-existence and interplay of different DLs at the organizational level. The analyzed company experiences the new digital culture through new businesses and 'young' companies integrated into the established structure. A closer inspection reveals that the willingness to change is obviously connected with firms' traditional structure and corporate size, with structural rigidities and a certain cost trap (factor C). In contrast to definitions such as "well organized" (INT-2M-005) or "process improved" (INT-2M-003), the interviewed managers regard the traditional organizational structure as an obstacle to innovation. In this context, they consider critically several positions like "oversized and unflexible" (EXT-2M-012), "restrained and conservative" (EXT-3M-013), and "kingdom with a centralized, à la command and control style" (INT-3M-009).

Indicators like fear and mistrust represent Factor D. Frequent mentions of these indicators reveal the impact of this factor on the managerial DL and the negative influence on an exploration turn. The empirical findings illustrate 
a traditional way of decision-making with a strong relatedness to power and status and a visible impact on the capacity to manage. The cross-over analysis of reasonings reveals that ideas and, even more, the readiness to manage the challenges are missing: in strategy, in competences and in terms of digital innovation. To bring oneself or a complete organization positively in line with radical, disruptive change, it takes a conscious, active influence of blocking dominant logic. This might be complicated by an (apparently) paradox situation. To create a new approach, the old one must be destroyed and forgotten. Fieldnotes 2017/03/15: This old approach was successful. And this approach might have been constitutive before, as a raison d'être. If so, nobody may be surprised that such a value is not given up without resistance. On the contrary, when such a destruction of the old happens, it first results in a gap that needs to be filled to prevent an emptying of meaning. We conclude:

RP4) Explorative DL-driven turns rest on a reduced role of power in leadership and formal structures.

Following Christensen's (1997) idea, digital disruption may only offer an opportunity if the players have the willingness to change and to act. For the incumbent company, it means a complete transformation: of the business and operating model, the organizational structure and the managerial logic. In other words, all four managerial capacities are influenced by DL, especially in times of digital disruption. To achive the explorative turn, a logic turn is also needed, a turn in the way how managers think and act. On the cognitive level, this implies transformation from firm's current DL based on 'exploitative' operational processes to a logic characterized as 'dynamic,' 'ambidexterous,' 'multiple,' and 'flexible.' Moreover, facing digital innovation, managers with previously defined abilities may design and execute the logic turn in an established organization.

Our aim was to locate the interplay between different DL mechanisms that enable an established company to consider challenges of an exploration turn of the disruptive kind. Moreover, our research propositions concerning 'capacity issues' could be a first step in how companies are operationalizing ideas for cognitive path-breaking and for the explorative turn. Thus, the cognitive process is essentially devoted to developing capacities that lead to the individual logic turn as well as to organizational adaptation to the innovative challenges from its environment. Fieldnotes 2017/03/5: The DL is still the same and did not show considerable differences. Shorthand reconstruction of conversation shows unanimous mood in all defined clusters: over-optimism mixed with allocation of blame. As for the results, case evidence suggests that the supposed change did not take place at the most important point in the 
minds of the people concerned. To follow up this development in the years to come might open an interesting field for further studies.

\section{DISCUSSION}

Prior research on DL revealed a set of factors that constitute, develop and maintain DL. Success in the past (Prahalad \& Bettis, 1986), core rigidities (Leonard-Barton, 1992; Greitemann et al., 2014), structural inertia (Kor \& Mesko, 2013; Shollo \& Constantiou, 2013), knowledge and learning (Teece, 2007; Gavetti, 2011), risk aversion and complexity reduction (Prahalad \& Bettis, 1986) and communication and information behavior (Walsh, 1995; Bettis \& Wong, 2003) are the structural factors that this study could build on. The data reveals the relevance of every single factor and, thus, allows the development of a holistic set of interrelated factors constituting the six-factor framework according to Figure 2, as one contribution of this study. Notably, the interplay of these structural factors is compatible to the Bettis and Prahalad (1995) framework of modeling DL-based behavior of organizations.

Another discourse relevant to responding to RQ2 is about the mechanisms that allow or prevent explorative turns. The case company is a prominent example that demonstrates how formerly rather successful and still strong companies (at least in terms of assets) struggle with starting exploration, although their old business models are already outdated and defective. Data reveals that four mechanisms, both stand-alone and in combination, explain the run of the explorative turn. The case company struggled with gearing these mechanisms of unlearning, exploring, changing and managing, which are another contribution of this study.

\section{CONCLUSIONS AND IMPLICATIONS}

This single case study responded to the research questions raised by pointing to the six-factor framework (RQ1) and the four process mechanisms of unlearning, exploring, changing and managing (RQ2). The more theoretical implications of this study relate to the developed set of research propositions as causalities for the sake of theorizing and model development as to how they influence exploration in the context of DL. These causalities may undergo follow-up research to specify or modify the causal relationships. Moreover, the empirical findings indicate several cognitive maps via 'factor-indicator connections' which influence DL and, thereby, the indirectly, unintentionally, and mostly unnoticed, explorative turns. 
As for the managerial implications of this study, the process mechanisms allow both driving and preventing explorative turns. Managers get to know decisive cornerstones for change management initiatives they can deal with - sometimes very much depending on context. A delicate question, however, is whether fostering or preventing explorative turns is beneficial or detrimental to the company. Not in every situation is there such a strong pressure to change as in the case company of this study. A preventing role of explorative turns by DL is not necessarily problematic but can be useful to avoid changes that might get out of control, so that 'self-security mechanisms' may work. However, a core challenge for managers is the management of the complexity of the factors relevant to manage explorative turns in the realm of DL. Another implication is about the way of turning a manager from an "innovation killer" (INT-3M-008) to an "innovation designer" (INT$2 \mathrm{M}-010)$. This implies considerable challenges, particularly on the cognitive level. Finally, one should not underestimate the threat that DL may become outdated in the light of running and future developments. This calls for the implementation of reflective mechanisms that help check how 'logical' DL is from a forward-looking viewpoint.

This research study has certain limitations we are aware of. First, we analyzed just a single case in a single country and in a single industry. Furthermore, this single case study could only consider a subset of people. Changing the context may imply different results. However, based on the intensive embeddedness of the authors' perceptions in connection with intensive observations, the researched contexts may represent a situation the entire company was or is in. Moreover, the multiple perspectives of interviewees helped to overcome potential biases. Second, the transformation process in the German power utility sector shows a very unique development and outlines the specific complexity level due to the influences of 'German Energiewende'. Therefore, the findings of this study should be approved in the energy markets of other countries and even more in other industries. Third, the set of findings relates to early explorative research and now offers the opportunity to be tested in further explorative and exploitative empirical studies. Fourth, the data collected is from 2016 and 2017. Although the organizational setting of the case company has been changed in the meantime, the situation regarding the analyzed phenomenon did not change significantly from then on. Key representatives of the management and the factors identified are still in place.

There are additional questions of interest for further research. What is still not considered sufficiently are the attributes that relate to the emotions of managers and managing teams. Sundermeier et al. (2020) pointed to the ambiguous role of hubris in leadership. For explorative turns in connection 
with $\mathrm{DL}$, the role of hubris could be interesting as hubristic leadership may drive or prevent the respective turns - and if it plays a role, then the impact can be rather strong. Contextual factors can play a pivotal role as well. This study dealt with a large, long-established company. However, are things different when it comes to small businesses or startups? Currently, the social and work environment has changed considerably due to the impact of the CoViD-19 pandemic. It may be important to understand how far this new and relevant context factor has impacted this study's topic.

\section{References}

Benner, M., \& Tripsas, M. (2012). The influence of prior industry affiliation on framing in nascent industries: The evolution of digital cameras. Strategic Management Journal, 33(3), 277-302. http://dx.doi.org/10.1002/ smj.950

Bettis, R. A., \& Prahalad, C. K. (1995). The dominant logic: Retrospective and extension. Strategic Management Journal, 16(1), 5-14. http://dx.doi. org/10.1002/smj.4250160104

Bettis, R.A., \& Wong, S. S. (2003). Dominant logic, knowledge creation, and managerial choice. In M. Easterby-Smith \& M.A. Lyles, (Eds.), The Blackwell Handbook of Organizational Learning and Knowledge (pp. 343-355). Malden: Wiley. http://dx.doi.org/10.1002/9781119207245.ch17

Beveridge, R., \& Kern, K. (2013). The 'Energiewende' in Germany: Background, development and future challenges. Renewable Energy Law and Policy Review, 4(1), 3-12.

Blau, A., \& Lubetsky, L. (2020, August 29). Leadership in turbulent times. Better foresight, better choices, Harvard Law School forum on corporate governance. Retrieved from https://corpgov.law.harvard. edu/2020/08/29/leadership-in-turbulent-times-better-foresight-betterchoices/

Blettner, D. P. (2008). The Evolution of Dominant Logic in Relation to Strategic Inertia in Software Ventures. St. Gallen: University Press.

Booth, A., Patel, N., \& Smith, M. (2020, September 3). Digital transformation in energy: Achieving escape velocity. McKinsey Insights. Retrieved from https://www.mckinsey.com/industries/oil-and-gas/our-insights/digitaltransformation-in-energy-achieving-escape-velocity\#

Brandtner, E., \& Freiling, J. (2019). Dominante Logiken. Barrieren oder Wegbegleiter für Schumpeters, schöpferische Zerstörung'? [Dominant logics. Barriers or companions of Schumpeter's creative destruction?]. In H.Frambach, N. Koubek, H.D. Kurz \& R. Pfriem (Eds.), Schöpferische Zerstörung und der Wandel des Unternehmertums [Creative Destruction and the Change of Entrepreneurship]. (pp. 97-119). Marburg: Metropolis.

Brown, T. A. (2015). Confirmatory Factor Analysis for Applied Research, 2nd ed., New York: Guilford. 
Buchan, D. (2012). The Energiewende - Germany's Gamble. Oxford: Oxford Institute for Energy Studies.

Butler, M., O’Broin, H., Lee, N., \& Senior, C. (2016). How organizational cognitive neuroscience can deepen understanding of managerial decision-making: A Review of the recent literature and future directions. International Journal of Management Reviews, 18(4), 542-559. http:// dx.doi.org/10.1111/ijmr.12071

Charmaz, K. (2014). Constructing Grounded Theory (2nd ed.). Thousand Oaks: Sage.

Chlebna, C., \& Simmie, J. (2018). New technological path creation and the role of institutions in different geo-political spaces. European Planning Studies, 26(5), 969-987. http://dx.doi.org/10.1080/09654313.2018.1441380

Christensen, C. M. (1997). The Innovator's Dilemma. Cambridge, MA: HBS Press.

Collan, M., Freiling, J., Kyläheiko, K., \& Roemer, E. (2014). Entrepreneurship and the art of tackling technological crises. International Journal of Technology Intelligence and Planning, 10(2), 166-185.

Corbin, J. \& Strauss, A. (2008). Basics of Qualitative Research: Techniques and Procedures for Developing Grounded Theory (3rd ed.). Thousand Oaks: Sage.

Danneels, E. (2004). Disruptive technology reconsidered: A critique and research agenda. Journal of Product Innovation Management, 21(4), 246-258. http://dx.doi.org/10.1111/j.0737-6782.2004.00076.x

Desai, J. (2013). Innovation Engine: Driving Execution for Breakthrough Results. Hoboken, NJ: Wiley. http://dx.doi.org/10.1002/9781118658925

Digital Vortex. (2019). Continuous and connected change. Global Center for Digital Business Transformation. Retrieved from https://www.imd.org/ contentassets/d4b328f064c844cd864a79369ba8405a/digital-vortex.pdf

Drucker, P. F. (1980). Managing in Turbulent Times. London: Routledge.

Fischedick, M., \& Grunwald (2017). Pfadabhängigkeiten in der Energiewende [Path dependencies in Energy Transformation]. Munich: Acatech.

Freiling, J. (2018). The exploitation trap of German small and medium-sized companies - ways in and ways out. In A. Oberheitmann, A. Elsner, C. Shengwei, \& X. Xuanguo (Eds.), Small- and Medium-sized Enterprises in Germany and China - Similarities and Dissimilarities (pp. 57-73). Essen: MA Verlag.

Freiling, J., \& Dressel, K. (2015). Exploring constrained rates of adoption of total cost of ownership models, a service-dominant logic analysis. International Small Business Journal, 33(7), 775-793. http://dx.doi. org/10.1177/0266242613519118

Freiling, J., Gersch, M., \& Goeke, C. (2008). On the path towards a competencebased theory of the firm. Organization Studies, 29(8/9), 1143-1164. http://dx.doi.org/10.1177/0170840608094774 
Friedrich von den Eichen, S.A., Freiling, J., \& Matzler, K. (2015). Why business model innovations fail. Journal of Business Strategy, 36(6), 29-38. http:// dx.doi.org/10.1108/JBS-09-2014-0107

Gancarczyk, M., Freiling, J., \& Gancarczyk, J. (2021). The dynamics of SME growth processes and the role of enabling constraints: An evidence-based theoretical framework. Journal of Organizational Change Management, 34(1), 180-205. https://doi.org/10.1108/JOCM-07-2020-0208

Gavetti, G. (2011). The new psychology of strategic leadership. Harvard Business Review, 89(7/8), 118-125.

Gibson, C. B., \& Birkinshaw, J. (2004). The antecedents, consequences, and mediating role of organizational ambidexterity. Academy of Management Journal, 47(2), 209-226. http://dx.doi.org/10.2307/20159573

Ginsberg, A. (1989). Constructing the business portfolio: A cognitive model of diversification. Journal of Management Studies. 26(4), 417-438.

Gioia, D. A., Corley, K. G., \& Hamilton, A. L. (2013). Seeking qualitative rigor in inductive research, notes on the Gioia methodology. Organizational Research Methods, 16(1), 15-31. https://doi. org/10.1177\%2F1094428112452151

Giones, F., Brem, A., \& Berger, A (2018). Strategic decisions in turbulent times: Lessons from the energy industry. Business Horizons, 62(2), 215225. http://dx.doi.org/10.1016/j.bushor.2018.11.003

Glaser, B. G., \& Strauss, A. (1967). The Discovery of Grounded Theory: Strategies for Qualitative Research. London, New York: Routledge. http://dx.doi.org/10.1097/00006199-196807000-00014

Govindarajan, V. (2012, March 26). Reversing the curse of dominant logic. Retrieved from https://hbr.org/2012/03/reversing-the-curse-of-domain

Grant, R. M. (1988). On 'dominant logic', relatedness and the link between diversity and performance. Strategic Management Journal, 9(6), 639642. http://dx.doi.org/10.1002/smj.4250090610

Greif, A., \& Laitin, D. D. (2004). A theory of endogenous institutional change. American Political Science Review, 98(4), 633-652. http://dx.doi. org/10.1017/S0003055404041395

Greitemann, J., Christ, E. E., Matzat, A. C., \& Reinhart, G. (2014). Strategic evaluation of technological capabilities, competencies and corecompetencies of manufacturing companies. Procedia CIRP, 19, 57-62. http://dx.doi.org/10.1016/j.procir.2014.05.017

Hake, J., Fischer, W., Venghaus, S., \& Weckenbrock, C. (2015). The German Energiewende - History and status quo. Energy, 92, 532-546. http:// dx.doi.org/10.1016/j.energy.2015.04.027

Hammersley, M. (2008). Troubles with triangulation. In M. Bergman (Ed.), Advances in Mixed Methods Research (pp. 22-36). London: Sage.

Helfat, C.E., \& Martin, J.A. (2015). Dynamic managerial capabilities: Review and assessment of managerial impact on strategic change. Journal of Management, 41(5), 1281-1312. http://dx.doi. org/10.1177/0149206314561301 
Hodgkinson, G. P., \& Wright, G. (2002). Confronting strategic inertia in a top management team: Learning from failure. Organization Studies, 23(6), 949-977. http://dx.doi.org/10.1177/0170840602236014

Huff, A. S. (1997). A current and future agenda for cognitive research in organizations. Journal of Management Studies, 34(6), 947-952. http:// dx.doi.org/10.1111/1467-6486.00079

Kane, G. (2017, August 7). 'Digital Transformation' Is a Misnomer. MIT Sloan Management Review. Retrieved from https://sloanreview.mit.edu/ article/digital-transformation-is-a-misnomer/

Kaplan, S. (2008). Framing contests: Strategy making under uncertainty. Organization Science, 19(5), 729-752. http://dx.doi.org/10.1287/ orsc. 1070.0340

Kelly, G. A. (1955). The Psychology of Personal Constructs. New York: Norton. Kor, Y.Y., \& Mesko, A. (2013). Dynamic managerial capabilities: Configuration and orchestration of top executives' capabilities and the firm's dominant logic. Strategic Management Journal, 34(2), 233-244. http://dx.doi. org/10.1002/smj.2000

Kukla, A. (2000). Social Constructivism and the Philosophy of Science. London: Routledge.

Lee, H., \& Lee, J. (2019). The paths of German energy transition: An institutional analysis. Journal of International and Area Studies, 26(2), 99-118.

Leonard-Barton, D. (1992). Core capabilities and core rigidities: A paradox in managing new product development. Strategic Management Journal, 13(1), 111-125. http://dx.doi.org/10.1002/smj.4250131009

Levinthal, D.A., \& March, J.G. (1993). The myopia of learning. Strategic Management Journal, 14, 95-112. http://dx.doi.org/10.1002/ smj.4250141009

Levitt, B., \& March, J. G. (1988). Organizational learning. Annual Review of Sociology, 14, 319-340. http://dx.doi.org/10.1146/annurev. so.14.080188.001535

March, J.G. (1991). Exploration and exploitation in organizational learning. Organization Science, 2(1), 71-87. http://dx.doi.org/10.1287/orsc.2.1.71

Markides, C. (2006). Disruptive innovation: In need of better theory. Journal of Product Innovation Management, 23(1), 19-25. http://dx.doi. org/10.1111/j.1540-5885.2005.00177.x

Pan, G. (2017). A dominant logic view of managing IT innovation. Journal of Information Technology Management, 28(4), 1-17.

Prahalad, C. K. (2004). The blinders of dominant logic. Long Range Planning, 37(1), 171-179. http://dx.doi.org/10.1016/j.Irp.2004.01.010

Prahalad, C. K., \& Bettis, R. (1986). The dominant logic: A new linkage between diversity and performance. Strategic Management Journal, 7(6), 485501. http://dx.doi.org/10.1002/smj.4250070602

Prahalad, C. K., \& Hamel, G. (1990). The core competence of the corporation. Harvard Business Review, 68(3), 79-91. 
Raffaelli, R., Glynn, M. A., \& Tushman, M. (2019). Frame flexibility: The role of cognitive and emotional framing in innovation adoption by incumbent firms. Strategic Management Journal, 40(7), 1013-1039. http://dx.doi. org/10.1002/smj.3011

Raynaud, H., \& Arrow, K. J. (2013). Managerial Logic. Hoboken, NJ: Wiley.

Ross, J. (2019). Don't confuse digital with digitization. In Who Wins in a Digital World? Strategies to Make Your Organization Fit for the Future (pp. 3-7). Cambridge, MA: MIT Press.

Selden, P.D., \& Fletcher, D.E. (2015). The entrepreneurial journey as an emergent hierarchical system of artifact-creating processes. Journal of Business Venturing, 30(4), 603-615. http://dx.doi.org/10.1016/j. jbusvent.2014.09.002

Shollo, A., \& Constantiou, I. (2013). Self-reinforcing mechanisms and organizational decision making. In J. Sydow \& G. Schreyögg (Eds.), SelfReinforcing Processes in and among Organizations (pp. 104-124). London: Palgrave Macmillian. http://dx.doi.org/10.1057/9780230392830.0013

Schumpeter, J. A. (1934). The Theory of Economic Development. Cambridge, MA: Harvard University Press.

Slater, S.F., \& Mohr, J.J. (2006). Successful development and commercialization of technological innovation: Insights based on strategy type. Journal of Product Innovation Management, 23(1), 26-33. http://dx.doi. org/10.1111/j.1540-5885.2005.00178.x

Sundermeier, J., Gersch, M., \& Freiling, J. (2020). Hubristic start-up founders - the neglected bright and inevitable dark manifestations of hubristic leadership in new venture creation processes. Journal of Management Studies, 57(5), 1037-1067. https://doi.org/10.1111/joms.12604

Sydow, J., Schreyögg, G., \& Koch, J. (2009). Organizational path dependence: Opening the Black Box. Academy of Management Review, 34(4), 689709. http://dx.doi.org/10.5465/AMR.2009.44885978

Teece, D. J. (2007). Explicating dynamic capabilities: The nature and microfoundations of (sustainable) enterprise performance. Strategic Management Journal, 28(8), 1319-1350. http://dx.doi.org/10.1002/ smj. 640

Teece, D. J. (2018). Business models and dynamic capabilities. Long Range Planning, 51(1), 40-49. http://dx.doi.org/10.1016/j.Irp.2017.06.007

Teece, D., Peteraf, M., \& Leih, S. (2016). Dynamic capabilities and organizational agility: Risk, uncertainty, and strategy in the innovation economy. California Management Review, 58(4), 13-35. http://dx.doi. org/10.1525/cmr.2016.58.4.13

Tversky, A. (1993). Cognitive maps, cognitive collages, and spatial mental models. In A.U. Frank \& I. Campari (Eds.), Spatial Information Theory a Theoretical Basis for GIS. (Lecture Notes in Computer Science, Vol. 716). Retrieved from http://dx.doi.org/10.1007/3-540-57207-4_2

Tversky, A., \& Kahneman, D. (1974), Judgement under uncertainty: Heuristics and biases. Science, New Series, 185(4157), 1124-1131. 
Vargo, S. L., \& Lusch, R. F. (2004). Evolving to a new dominant logic for marketing. Journal of Marketing, 68(1), 1-17. http://dx.doi.org/10.1509/ jmkg.68.1.1.24036

Vargo, S. L., \& Lusch, R. F. (2007). From goods to service(s): Divergences and convergences of logics. Industrial Marketing Management, 37(3), 254259. http://dx.doi.org/10.1016/j.indmarman.2007.07.004

Walsh, J.P. (1995). Managerial and organizational cognition, notes from a trip down memory lane. Organization Science, 6(3), 280-321. http://dx.doi. org/10.1287/orsc.6.3.280

Wang, J., Hedman, J., \& Tuunainen, V. K. (2016). Path creation, path dependence and breaking away from the path: Re-examining the case of Nokia. Journal of Theoretical and Applied Electronic Commerce Research, 11(2), 16-27. http://dx.doi.org/10.4067/S0718-18762016000200003

Weick, K. E., \& Sutcliffe, K. M. (2007). Managing the Unexpected: Resilient Performance in an Age of Uncertainty, San Francisco: Jossey-Bass.

Wessel, L., Baiyere, A., Ologeanu-Taddei, R., Cha, J., \& Jensen, T. B. (2020). Unpacking the difference between digital transformation and IT-enabled organizational transformation. Journal of the Association for Information Systems, 22(1), 102-129. https://doi.org/10.17705/1jais.00655

Wolfinger, N. H. (2002). On writing fieldnotes: Collection strategies and background expectancies. Qualitative Research. 2(1), 85-95. http:// dx.doi.org/10.1177/1468794102002001640

Yin, R. K. (2014). Case Study Research Design and Methods (5th ed.). Thousand Oaks: Sage.

\begin{abstract}
Abstrakt
Cel: Niniejsze badanie ma na celu określenie roli „dominujqcej logiki” w organizacji. $W$ ten sposób pojawia się niejednoznaczny charakter dominujqcej logiki, ponieważ z jednej strony dominujqca logika może nadać sens zmianie, dostarczyć użytecznych wskazówek i utrzymać koncentrację firmy. Jednak z drugiej strony dominująca logika może dostarczyć powodów, dla których zapobieganie zmianom może być "logiczne” lub działać jako zasłona, jeśli chodzi o interpretację nadchodzqcych zmian. Dlatego dominujqca logika może być wartościq i zobowiqzaniem w czasach zmian. Metodyka: Niniejsze studium ma na celu wniesienie wkładu do wcześniejszych badań poprzez postawienie dwóch pytań. Po pierwsze, w jaki sposób możemy ponownie konceptualizować konstrukcję dominujqcej logiki, aby odnieść się zarówno do roli kierujqcej, jak i utrudniajqcej w przypadku zwrotów eksploracyjnych? Po drugie, które czynniki ograniczajq, a które umożliwiajq zwroty eksploracyjne? Ze szczególnym uwzględnieniem niemieckiej transformacji energetycznej w roku 2010, niniejsze badanie opiera się na eksploracyjnych badaniach empirycznych jakościowych i wykorzystuje pojedynczy projekt studium przypadku dla tradycyjnego niemieckiego przedsiębiorstwa energetycznego, które - jako operator - musi radzić sobie z dużq złożonościq niemieckiej energetyki. Źródła danych to pogłębione i skoncentrowane na problemie wywiady z ekspertami wewnętrznymi i zewnętrznymi, a także obserwacje terenowe. Procedura
\end{abstract}


indukcyjna pozwala na opracowywanie propozycji badawczych na podstawie danych, ujętych w ramach wcześniejszych badań. Wyniki: $W$ rezultacie niniejsze badanie dostarcza sześcioczynnikowej ramy, aby rzucić światło na mikro-podstawy dominujqcej logiki. To, czy dominujq̨ca logika ma wartość, czy też jest odpowiedzialnościq za zmianę organizacyjnq i umożliwia zwrot eksploracyjny, zależy od zidentyfikowanych zdolności do oduczania się, eksploracji, zmiany i zarzq̨dzania. Dane sugerujq, że zwrot eksploracyjny, napędzany dominujqca logikq, działa lepiej w przypadku połqczonych zdolności uczenia się i oduczania się, równowagi eksploracji i eksploatacji, wspótistniejqcej logiki, ciqgłłej adaptacji dominujqcej logiki i niższych poziomów siły przywódczej i formalnej struktury. Implikacje dla teorii i praktyki: To badanie określa rolę dominujqcej logiki, która może utrudniać zwroty eksploracyjne w czasach poważnych zakłóceń. Oryginalność i wartość: Przyczynia się do badań poznania menedżerskiego poprzez udoskonalenie i zastosowanie pojęcia logiki dominującej. Ponadto dostarcza empirycznych dowodów na to, w jaki sposób zjawisko to wywołuje inercję i napędza zmiany, a także umożliwia dyskusję na temat potrzeb i barier dla zwrotu eksploracyjnego. Z menedżerskiego punktu widzenia dominujqca logika służy jako filtr identyfikujqcy wymagane zmiany i dostosowujq̨cy szybkość zmian. Zależy to jednak od menedżerskiej refleksji nad stosownościq dominujq̨cej logiki w biegu wydarzeń.

Słowa kluczowe: logika dominujqca, zwrot eksploracyjny, pułapka eksploatacyjna, niemiecka transformacja energetyczna.

\section{Biographical notes}

Ekaterina Brandtner is Ph.D. candidate at the Chair of Small Business \& Entrepreneurship (LEMEX) at the University of Bremen, Germany. She has a master's degree in Business Administration, General Management at the University of Wales, UK. Her research interests include innovation and strategic management.

Jörg Freiling is Full Professor and Head of the Chair of Small Businesses \& Entrepreneurship (LEMEX) at the University of Bremen, Germany. Simultaneously, he is Vice Dean of the Faculty for Business Studies and Economics. His research focuses business model innovation, transnational entrepreneurship, entrepreneurial ecosystems, corporate entrepreneurship, and incubators and accelerators.

\section{Conflicts of interest}

The authors declare no conflict of interest. 


\section{Citation}

Brandtner, E., \& Freiling, J. (2021). Is dominant logic a value or a liability? On the explorative turn in the German power utility industry. Journal of Entrepreneurship, Management and Innovation, 17(2), 125-157. https://doi. org/10.7341/20211725 